This is a self-archived - parallel published version of this article in the publication archive of the University of Vaasa. It might differ from the original.

\title{
Short-term Assignees, International Business Travellers and International Commuters
}

Author(s): Brewster, Chris; Dickmann, Michael; Suutari, Vesa

Title: $\quad$ Short-term Assignees, International Business Travellers and International Commuters

Year: $\quad 2020$

Version: Accepted manuscript

Copyright (C) Cambridge University Press 2020. This material has been published in revised form Global Mobility and the Management of Expatriates edited by Bonache, J., Brewster, C. \& Froese, F.J. [http://doi.org/10.1017/9781108679220]. This version is free to view and download for private research and study only. Not for redistribution or re-use.

\section{Please cite the original version:}

Brewster, C., Dickmann, M. \& Suutari, V. (2020). Short-term Assignees, International Business Travellers and International Commuters. In: Bonache, J., Brewster, C. \& Froese, F.J. (Eds.) Global Mobility and the Management of Expatriates, 153-180. Cambridge: Cambridge University Press. https://doi.org/10.1017/9781108679220.007 


\section{Chapter 7:}

\section{Short-term Assignees, International Business Travellers and International Commuters}

Chris Brewster, Michael Dickmann, and Vesa Suutari

In J. Bonache, C. Brewster and F.J. Froese (Eds.). Global Mobility and the Management of

Expatriates. Cambridge: Cambridge University Press. DOI: 10.1017/9781108679220

People can work internationally without being classified as expatriates or migrants. This chapter explores these alternative options, focusing, in particular, on three of the main alternative 'other' ways of arranging international work: short-term assignments (STAs), international business travel (IBTs) and international commuting (McNulty \& Brewster, 2019). Whilst expatriates are people who go to work in another country on a temporary basis but for a number of years and migrants are people who go to work in another country expecting to settle down there (McNulty \& Brewster, 2017), the 'other' ways of working in another country tend to be shorter and, crucially, do not involve relocating 'home' or taking the family, if there is one, with them.

As is always necessary, we note the fungibility of the categories we explore and we discuss that briefly below: international business travellers are sometimes already expatriates, and some international commuters do not retain a permanent home in their own country; people who start as short-term assignees may be asked to stay on and become expatriates, and so on. But the categories indicate important classes of people who have to date received much less research attention than expatriates or migrants, even though there are substantial numbers in each group.

Each of the three major categories of 'other' international work - STAs, IBT and international commuting - can be either organisationally initiated or can be self-initiated and we note these variations as we explore the topic. Common to all three main alternative types of international work is that the period of time they spend outside the home country is relatively short: during the working day only or varying from a few days to one year (Mäkelä, Sarenpaa \& McNulty, 2017) - if it is longer than that, of course, they meet the criteria for 'expatriation'. Serious research on this large group of international workers is 
limited; some of the best information and reports that we have about 'other' international workers and the opportunities and challenges that they and their employers face have to be taken from the consulting field. Scholarly work is, as we shall show, only slowing catching up.

From the organisational perspective, consultancy reports predict that whilst long-term expatriation is forecast to stay at about current levels, or to grow only slowly, these other kinds of work are expected to grow by more than half over the next few years (KPMG, 2017). It seems that similar patterns can be found in all regions of the world (Cartus, 2018; Johnson, 2017). For the organisation these could be cost-effective ways of working that fit business requirements. The one-off, up-front costs are more attractive than commitment to costs over a long period of time (Air Inc, 2018; Johnson, 2017). Expatriation is expensive for organisations and they are continually seeking ways to reduce the costs of getting work done internationally, whilst trying to gain some, though necessarily not all, of the benefits of expatriation. 'Other' international workers are normally cheaper than expatriates, staying on home country salaries, with fewer additional benefits and perks. Because assignments are short, families do not accompany them, and that is cheaper for the employer. In addition, administration is more straightforward, and hence cheaper, because in most cases no international tax liabilities are created (Duxbury, 2018). In nearly all cases, the employment contract remains in the home country and is administered under its terms and conditions (Mäkelä et al., 2017).

Yet these cheaper 'other' international assignments have some (though not all) of the benefits of expatriation. They can bring needed skills to a specific location (Mäkelä et al., 2017; Minbaeva \& Michailova, 2004), they are flexible (Brookfield Global Relocation Services, 2009; Air Inc, 2012) and they fit with operational requirements. In addition, the use of, for example, commuter assignments may be safer than expatriation to a dangerous territory (Welch \& Worm, 2006)

One consequence is that much of these 'other' forms of international work are outside the purview of the Global HRM function, where the specialists are responsible for expatriation, and the local HRM function, where the specialists may know about and be trying to integrate migrants. Neither has responsibility for the other forms of international work, 
which are largely controlled by line managers: the organisation as a whole may not even have a clear view of how many people they have in each of these categories.

For the people who are on short-term assignments or travelling frequently or commuting, these patterns may be convenient or safer or they may just be part of the way their job is done and, perhaps, always has been done. We explore the advantages and disadvantages of each form of work for each of the key stakeholders as we address them in turn.

\section{SHORT-TERM ASSIGNEES}

Overview

Though empirical research has been scarce, there has been increasing discussion in the literature about short-term assignments (Suutari \& Brewster, 2009; Harvey, Mayerhofer, Hartmann \& Moeller, 2010; Collings, McDonnell \& McCarter, 2015; Mäkelä et al., 2017). Such assignments are typically defined as lasting less than a year (Tahvanainen, Worm \& Walsh, 2005: 7; Collings et al., 2015) though in practice they commonly last less than half a year, due to the tax, insurance and social security implications of longer assignments (Suutari, Brewster, Riusala \& Syrjakari, 2013; Collings et al., 2015).

While many organisations aim to reduce the number of long-term assignments the use of STAs appears to be increasing, though our evidence is still quite limited and relies largely on consultancy reports. For example, a survey by Mercer (2016) reported that organisations are more likely to deploy STAs than long term assignees; and a report by ECA International (2016) found the use of STAs was already $22 \%$ of all assignments, compared to $14 \%$ in 2008 , and was increasing further. There are academic studies reporting similar increases (Kang, Shen and Benson, 2016).

\section{Motives and barriers}

These increases have taken place due to reasons such as such as better transportation and communication systems, wider organisational networking, more flexible intra-organisational coordination of global units, and cost containment initiatives (Harvey et al., 2010). STAs are often used for problem solving on specific issues that do not require longer term expatriation (Collings et al., 2015). Typical work has been found to relate to tasks such as construction projects, spreading changes, managing projects and expanding the company's 
market (Salleh \& Koh, 2013). STAs are often thus involved in project work that is required for some months but then ceases. They allow temporary access to specialised talent that requires the moving of people to other countries (Hocking, Brown \& Harzing, 2004). Sending a skilled person to fix a problem will be considerably quicker and easier than training up local staff or trying to resolve a problem at a distance (Meyskens, Von Glinow, Werther \& Clarke, 2009; Tahvanainen et al., 2005). STAs can also be utilised in management development programmes (Salleh \& Koh, 2013). In that respect, STAs at headquarters for foreign subsidiary unit employees, or, 'inpatriation' - from an ethnocentric viewpoint - offer technical training and learning about the corporate culture (Harvey et al., 2010; Reiche, Harzing \& Kraimer, 2009). At the same time, inpatriates can bring host country knowledge into the headquarters. Overall, STAs can become an important source of information relevant to developing relationships in global networks and can, thus, facilitate knowledge sharing across borders (Harvey et al., 2010; Minbaeva \& Michailova 2004).

At the same time, employee interests also support the growth of short-term assignments: they are much easier for assignees and their families. Though the absence of assignees for a period can disturb family daily life for anything up to several months, the partners can still continue their own careers and children can continue their schooling uninterrupted (Dickmann, Suutari \& Wurtz 2018: 13). Furthermore, and again from the organisational perspective, since partners or families typically stay at home, the costs involved with these 'extra' people - which are significant- are much lower than in the case of long-term expatriation (Starr \& Currie 2009; Tahvanainen et al., 2005).

For assignees, STAs can offer a change of routine (Crowley-Henry \& Heaslip, 2014). They can provide the opportunity of working in and getting to know about another country - although some individuals, sometimes called FIFO, or fly-in-fly-out contractors (Blackman, Welters, Murphy, Eagle, Pearce, Pryce, Lynch \& Low, 2014), are 'off-shore' or in remote locations. In all cases they offer self-development opportunities (Starr \& Currie 2009). Adjustment occurs on a positively skewed distribution, with most learning taking place in the first few months (Haslberger, Brewster \& Hippler, 2014), so short-term assignees may get similar developmental benefits to many long term expatriates. Therefore, STAs can be a form of training (Crowne \& Engle 2016), particularly in inpatriate assignments, and they can develop managerial skills (Crowley-Henry \& Heaslip, 2014), project skills (Suutari et al., 2013), and 
offer the possibility to experience new cultures and business practices (Harvey et al., 2010; Reiche, Harzing \& Kraimer 2009). STAs may be a useful way to give young potentials international work experience (Mayrhofer \& Scullion 2002; Starr \& Currie 2009; Suutari et al., 2013) that such people often value (Collings et al., 2015). For people from emerging economies they can be a good way of getting their first international experience and of polishing their English (Harjo, Chung \& Brewster, forthcoming)

Though the research evidence on STAs is limited, both from the individual and organisational angles, the existing research has already covered STA experience from several perspectives. For example, Starr and Currie (2009) analysed the role of the family in the STA process, Crowne and Engle (2016) studied the cross-cultural adaptation stress of assignees and Starr (2009) explored the 'repatriation' experiences of such assignees. There have also been several studies from the organisational perspective such as studies by Salleh and Koh, (2013) that analysed the purposes of STAs, and Crowley-Henry and Heaslip (2014) who focused on the use of STAs in the military sector. Several case studies have examined human resource management processes around STAs: Tahvanainen, Welch and Worm (2005) investigated the use and management of STAs and Suutari et al (2013) reported on development processes related to the management of different alternative assignment types within one MNC.

\section{Management of STAs}

Although we have noted several reasons for the increased use of STAs within companies, there are also some disadvantages for the employing organisation and for the assignees. The management challenges involve administrative issues connected with the individual's taxation and social security issues, particularly if the assignment lasts longer than six months (Collings et al., 2015; Tahvanainen et al., 2005). In some countries the need for visas and work permits, especially in locations where the company does not yet have an affiliate, can create problems (Collings et al., 2015; Tahvanainen et al., 2005). There are also problems of allocating responsibility. Many STAs are costed within the budget of the line manager and often managed by them with little support from the IHRM department (Brewster, Harris \& Petrovic, 2001). There can therefore be problems of co-ordination and of appropriate compensation. However, there are some signs that companies are developing explicit STA policies and practices including stringent reward rules (Dickmann, 2016). 
It can be difficult for STAs to become integrated into the local workplace and host community, hence they find it harder to develop effective relationships with local colleagues and customers (Tahvanainen et al., 2005). Since they have little time to adjust to local ways of doing things, those in non-technical jobs, in particular, may find that individual adjustment problems cause challenges for the well-being and performance of the whole group (Suutari et al., 2013). The partner and family may not move abroad during the STA, but the absence of the assignee impacts family life in other ways, adding extra burdens to the partner and the children, and can lead to family stress and difficulties in work-life balance (Meyskens et al., 2009; Starr \& Currie 2009; Tahvanainen et al., 2005). It is relatively easy to communicate with the family in the era of Skype, Facetime, WhatsUp, Kick, Facebook and other social media sites (Bonache, Brewster, Suutari \& Cerdin, 2018), but no technology can replace the actual presence of the complete family. In turn, without family responsibilities, the expatriate can focus on their work: short term assignees typically put in long hours at the plant or in the office. This may lead to problems of stress and fatigue (Tahvanainen et al., 2005). Short-term assignees typically live in hotels or, for more remote locations (oil rigs, pipelines, etc.), in company provided dormitories or similar accommodation. Once off work, particularly in countries where they cannot speak the language and in less developed countries, there is little to do other than go back to their sleeping quarters. For some the result will be boredom, heavy drinking and/ or depression (Wurtz, 2018); others will find themselves taking risks they would not do when they were at home with their family.

In order to succeed in the management of short-term expatriation, many multinationals have been developing their STA policies and practices. For example, Mäkelä, Saarenpää and McNulty (2017) argue that consultancy reports indicate that STAs may be more systematically managed than is apparent from the extant research evidence. There is limited case study evidence examining the issue from the perspective of human resource management (Tahvanainen et al., 2005; Suutari et al., 2013). In practice, the role of line managers is, however, often central in the process and the follow-up of assignments, the costs involved or the overall success of assignments (Collings et al., 2015; Dickmann, 2015). The lack of basic monitoring of these assignments means that learning becomes difficult and 
many of the challenges involved in working abroad are left to assignees themselves to deal with.

The selection of assignees appears to be mostly informal, involving little bureaucracy, even if HRM specialist may be aware that a more formalised selection process would avoid an over-reliance on line managers' personal contacts (Kang et al., 2016; Tahvanainen et al., 2005; Suutari et al., 2013). This over-reliance on personal contacts can also lead to a critical shortage of internationally experienced project staff. Still, our evidence on selection processes is very limited (Collings et al., 2015).

The administrative issues related to STAs may be dealt with by IHRM or global mobility units (Collings et al., 2015) while taxation, and alignment to immigration regulations, are frequently outsourced to mobility service providers (Dickmann, 2016). With regard to STAs lasting less than six months, salary payment and associated taxes, insurances and pension arrangements typically remains in the home company and country, the home country salary forms the basis for compensation for more than three quarter of STAs (Dickmann, 2016). The assignee typically continues on the same contract that they were on at home (Kang et al., 2016). Sometimes the company's travel policy may form a basis for additional rewards (Tahvanainen et al., 2005) and they thus get a per diem: a (tax free) daily allowance and a hardship allowance when needed (Collings et al., 2007). For assignments over six months, more detailed contracts can be organised, and in many countries such contracts are required also in the host country (Suutari et al., 2013).

\section{Future research avenues}

Clearly, given their numbers and importance we need to know more about STAs. We know little about their selection. We are just beginning to get research into the issues raised for businesses in the emerging countries which shows that for Indonesia, for example, adult employees offered a short-term assignment seek approval from their parents and are often influenced by the religion of the country they are being assigned to (Harjo, et al., forthcoming)

There has been almost no research on the requirements for training among other types of assignees than long-term assignees (Collings et al., 2007). Training of STAs is still often limited due to the restricted time for preparation, the costs of training and a lack of 
understanding of the need for training (Suutari et al., 2013). Such a lack of preparation may have negative impacts for both organisations and individuals (Collings et al., 2015). It may hinder the integration of assignees with the local workforce, restrict their adaptation to local practices and limit the performance of the assignees (Tahvanainen et al., 2005). Sometimes, if cultural distance is higher between the home and host country, some training may be provided, though even here it is on a voluntary basis and only available if the timing works out (Kang et al., 2016). In case of more difficult environments, some training about travel and health \& safety in foreign countries may be given (Collings et al., 2007). If an STA is itself used as a tool for professional or managerial development, nominating a mentor with defined responsibilities, more careful planning of such assignments and in-depth evaluation of learning is also seen as necessary (Suutari et al., 2013).

Given that the training of assignees is rare, it is not surprising to find that the further step of family support is even less often offered (Tahvanainen et al., 2005), but again we have little empirical evidence. The organisations that do provide support typically grant additional family leave and finance flights home (Dickmann, 2016). In those few cases where the STA lasts longer, the family may accompany the assignee and the company may pay the related costs (Tahvanainen et al., 2005). In a case reported by Suutari et al (2013), the company had started arranging visits and providing informal guidance for the whole family in order to reduce the problems involved.

We have little data about what happens after the assignment. Given that such individuals are away for less time than long-term assignees, repatriation should be easier, but we lack empirical evidence (Tahvanainen et al., 2005). Nevertheless, it has been reported that repatriation and integration back home may still not be without problems (Starr, 2009). STAs were found to sometimes build expectations about upward mobility and new jobs after the international mobility experience and may get disappointed when such expectations are not met. Whether such experiences impact on intentions to leave deserves further research attention (Collings et al., 2015).

Not all STAs lead to repatriation and continued employment in the organisation. In some cases, assignees may be recruited specifically for the role - this is typical for specialists in information technology, in resource exploration or in short-term expatriation to dangerous environments. At the end of the contract such assignees often leave the organisation. 


\section{INTERNATIONAL BUSINESS TRAVELLERS}

\section{Overview}

An international business traveller or, as they are sometimes called a 'frequent flyer', is someone "for whom business travel is an essential component of their work" (Welch \& Worm, 2006: 284). Crucially, IBTs do not relocate, differentiating them from STAs and other forms of assignees. And they normally travel to several different countries and on less regular patterns, which sets them apart from international commuters. The duration of their visits is defined by the goals of their work and they may be involved with a range of teams in different countries (Collings et al., 2015).

The last decades have seen an increase in international business travel (DeFrank et al., 2000; Hovhannisyan \& Keller, 2015, Brookfield, 2013) and it has been common to assume that this trend will continue. The value of the global business travel market is already well over \$1 trillion and forecast to grow to $\$ 1.3$ trillion by2023 (Allied Market Research, 2018). Many authors have pointed to patterns of globalisation and the increased need for cooperation, innovation and trust across units that operate in different countries. While some of these factors are clearly right, we are currently witnessing a strong societal trend emerging that may limit this growth. Global warming and the need to reduce carbon emissions has become central in the political and environmental discourse of many societies and the pressure to limit one's carbon footprint is increasing. While this has yet to manifest itself in less international travel it remains a distinct possibility that many MNCs may take drastic actions to use more virtual means of business meetings and coordination. This may decrease costs and their carbon footprints further while alleviating some of the pressures on IBTs to travel as frequently as before.

There are different perspectives that can be used to explore the issues involved in IBTs. We have chosen to use a temporal perspective that focuses predominantly on individual, organisational and family characteristics. As with other expatriation models (Harris, Brewster \& Sparrow, 2003) it employs a temporal view and takes account of the mutual dependency of international workers and their employers (Larson, 2004). Given, however, that international travel may be part of a normal career pattern in a multinational 
organisation we have developed a double helix framework that indicates that the endings might also be new beginnings in another position that equally involves international travel. $<<$ Insert Figure X: The Double Helix of IBTs - Combining Perspectives about here >> Source: Michael Dickmann

Work as an IBT is distinct from work as an expatriate who relocates to a foreign country. The pressures on expatriates have been depicted through the expatriation cycle (Harris et al., 2003). While a mutual dependence between organisation and individuals obviously exists for IBTs, its nature is distinct. Expatriates depend most on their organisation when they are moving abroad - for household shipping, schooling, accommodation, health provision etc. and when they are returning from abroad (predominantly for the physical relocation and for gaining a 'good' job in the next location). For IBTs this dependency has different nuances (the focus is on travel arrangements, security, health implications) and it is more evenly stretched in time and in relation to all their travel activities. Thus, the organizational support needed is distinct. The family - which does not move abroad - is affected in a different way. In addition, the learning that IBTs are likely to accumulate is less single foreign location specific and may include some more transferable skills and insights (Baruch et al., 2013). The double helix of IBTs depicts the interplay and complex interdependencies between individuals, organizations and the wider context.

\section{Motives and barriers}

Why do organisations use IBTs? It is argued that the costs of business travel are lower than traditional expatriation and that the flexibility of their use - IBTs can work in a variety of locations, on diverse projects etc. - is superior (Collings, et al., 2015). In addition, they may support the integration of organisational culture and the achievement of common standards. IBTs can have similar control and coordination as well as knowledge transfer roles to other forms of international work assignments (Edström \& Galbraith, 1977; Harvey, et al., 2010). In addition, face-to-face meetings and (physically) joint work is still often seen as beneficial for trust-building and to cement personal relationships amongst the key stakeholders in projects or more permanent work teams (Beaverstock, Derudder, Faulconbridge \& Wilcox, 2010; Davidson \& Cope, 2003; Mäkelä \& Brewster, 2009). Little is known about how IBTs are selected for their jobs and whether it is linked to strategic goals. 
Operationally, however, Demel and Mayrhofer (2010) suggest that multinationals should improve their selection mechanisms to go beyond technical expertise and cultural insights and skills. They suggest that physical fitness, persistence, resilience and self-discipline should also be assessed given some of the challenges outlined below.

The organisational drivers that may guide the use of IBTs in MNCs include cost, cultural and operational issues, in that IBTs are seen as a more cost-effective variant of international work than traditional expatriation whilst still allowing cultural coordination and operational integration. The effects of IBTs within specific business configurations (Bartlett \& Ghoshal, 2002 ) in relation to control and coordination, innovation, cost, leadership development and knowledge transfer (Dickmann \& Müller-Camen, 2006) have not been explored holistically. Nevertheless, work has emerged that looks at some sub-section of these issues. For instance, Hovhannisyan and Keller (2015) find that increased business travel is correlated with an increase in patenting in organisations. There is also some indication that IBT costs are lower than those of traditional expatriation (Collings et al., 2015) although tracking these costs is difficult and not well executed (Dickmann, 2018). Crucially, cost is not equal to value and MNCs are traditionally weak in assessing value in global mobility (McNulty, DeCieri \& Hutchings, 2009; Renshaw, Parry \& Dickmann, 2018).

IBTs themselves might be driven by a mixture of factors that determine their willingness to work abroad while wanting to keep their 'home base'. People with a global mindset and an international career orientation are seen to be more likely to accept or seek cross-border business travel (Philllips, Gully, McCarthy, Castellano \& Kim, 2014; Kedia \& Mukherji, 1999). Conversely, if they were to decline to travel this might harm their career prospects (Shaffer, Kraimer, Chen, \& Bolino, 2012) as travelling might be seen as a "must for career development" (Demel \& Mayrhofer, 2010: 305). However, there may be a range of further considerations that guide the decision to undertake frequent international business travel, including health, learning, having a respite, monetary and family elements (Beaverstock et al., 2010; Demel \& Mayrhofer, 2010; Westman \& Etzion, 2002; Westman, Etzion \& Chen, $2009 b)$. Concerns about the security of the host location if the family were to relocate, for the career of the partner (for instance avoiding the dual career problem of long-term expatriation), or for the non-interruption of the education of children are likely to be substantial in shaping individuals motivation to become an IBT (Dickmann \& Baruch, 2011). 
The IBT literature has explored the individual experience of the global worker in detail, identifying a range of negative effects. More than two decades ago Rogers (1998) found that international travel often results in physical and psychological health issues. Striker, Luippold, Nagy, Liese, Bigelow and Mundt (1999) identified risk factors that led to stress amongst World Bank IBTs. Working abroad for some time, separated from one's family and often on schedules that are very crowded and dynamic may lead to job, social and emotional worries. For instance, IBTs would worry about the impact of their absence on their family, social links and work upon return. DeFrank, Konopaske and Ivancevich (2000) point out that international travel may be associated with emotional upset and even in some cases physical illness. While any solo travel is associated with being away from loved ones and friends, international journeys often imply differences in time zones, languages, culture, safety contexts, customs and business practices - all of which place higher demands on IBTs. In addition, physical effects such as an unbalanced diet, more food and alcohol intake and other health concerns are frequently associated with international travel (Demel \& Mayrhofer, 2010). Thus, compared to domestic trips, IBTs feel more mental and physical strain (Baker \& Ciuk, 2015) and they can experience loneliness and burnout (Collings et al., 2015). They also suffer work-family conflict and sleeping problems (Mäkelä, Bergbom, Tanskanen \& Kinnunen, 2014).

Where IBTs perceive an imbalance between their efforts and resulting rewards, this can increase work to life conflict (Mäkelä et al., 2015.) However, positive effects are also possible. For instance, in the same study it was found that a low effort-reward imbalance can support work to life enrichment if coupled with a pronounced international career orientation.

Clearly, IBT affects not only organisations and their staff but also impacts a wide variety of other stakeholders such as the family and friends of the cross-border traveller. It is not only global workers who suffer from increased stress but also their partners, especially if they had young children, if travel plans are changed frequently or if their partners (in the case of female partners) were young (Espino, Sundstrom, Frick, Jacobs \& Peters, 2002). The workfamily interface in IBTs seems to be affected predominantly by the range of key factors outlined above: the length of absence, control of the global worker of the travel schedule, predictability of travel periods and organisational support measures (Baker \& Ciuk, 2015). In 
international work the boundaries of family and work are blurred (Caligiuri, Hyman, Joshi \& Bross, 1998; Lazarova, Westman \& Shaffer, 2010) and this general observation regarding expatriates is likely to extend to IBTs, too. It is, therefore, no surprise that IBTs themselves had a range of negative feelings when travelling 'too much' - they could not attend important family gatherings, other key events in the lives of their children and partners or were not available when a crisis happened (DeFrank et al., 2000; Espino et al., 2002; Demel \& Mayrhofer, 2010). Their partners echoed these negative impressions. While negative effects have been explored in more depth there are a range of potential positive effects of international business travel that could be more thoroughly investigated. These include the effects of absence on the time that partners and families are able to spend together (e.g. the 'golden weekend or holidays'), the insights and other positive spill-over effects that IBTs can bring back into their families (see Mäkelä et al., 2014 and Westman et al., 2009 for some exploration) or the effects of IBTs on host unit teams.

IBTs are not traditional expatriates so that some of the expected outcomes of their international work are different. Given that they are less embedded in a foreign host culture and that they generally work less time abroad their cultural experiences are different and the likely cultural adjustment to one host culture is lower (Baruch, Dickmann, Altman \& Bournois, 2013). While their cross-cultural agility (Caligiuri, 2012) may well be high as they have to adjust to potentially many countries and host contexts, so their cultural learning is likely to be different. Demel and Mayrhofer (2010) found IBTs had some negative and some highly positive expectations in relation to the outcomes of their international work on future careers. The positive expectations included gaining valuable professional, project and personal experiences, building useful networks abroad and acquiring a strong and positive reputation that would allow them greater choice of career possibilities.

A large range of negative and some positive work-family and work-life spill-over effects from international business travel have been outlined above. It is clear that the absence from one's family and social network has some major short-term effects in terms of stress, feeling of loneliness and worry. Amongst the longer-term effects are 'burn-out' and enduring family tension. In addition, because IBTs are likely to have highly unpredictable patterns relating to when they are 'at home' their whole social network and activities may suffer long-term damages. Saarenpää (2017) outlines an extensive range of negative work-family balance 
issues - exploring these holistically in the long-term would aid our understanding of how to manage IBTs and how to select them greatly (Demel \& Mayrhofer, 2010).

\section{Management of IBTS}

Because international business travel is part and parcel of certain jobs in multinational enterprises, the information on tailored HRM approaches is sparse. Very few organisations have their HRM or GM departments involved in setting separate policy guidelines for crossborder travellers. Where the international trips are especially long - extended business trips that often trigger compliance issues - about a quarter of larger firms have dedicated policy approaches (Dickmann, 2018: 83). Enterprises also occasionally have different reward approaches where IBTs may get some extra remuneration. However, the likelihood that IBTs attract a mobility premium, cost of living, hardship or home leave allowance is lower for IBTs than for short-term, long-term or commuter assignments (Dickmann, 2018: 88). In addition, it seems that HRM support practices such as cross-cultural training are predominantly aimed at other forms of international working - ignoring IBTs (Harvey et al., 2010; Mäkelä et al., 2015). This is not to argue that organisations should not devise special policies or practices for IBTs. It is known, for instance, that where IBTs have more control over their resources and trip numbers, this is associated with travellers having higher vigour (Westman, Etzion \& Chen, 2009a); and efficient and safe travel arrangements as well as the opportunity to rest after a stay abroad are related to higher IBT satisfaction (Beaverstock et al., 2010). An early article listed a range of organisational and individual activities that could help to manage traveller stress (DeFrank, Konopaske \& Ivancevich, 2000: 67).

Given that cross-border business travel is associated with many professional career paths in multinational enterprises and seen as 'part of the job', it is highly likely that global mobility departments are not involved in the selection and management of IBTs. In fact, in many cases GM professionals complain about having insufficient data about travel patterns (some might get these via their travel agencies) and see major tax and compliance risks (Brookfield GMAC, 2013). Assuring legal compliance, eg that IBTs have the right working visa and that all corporate and individual taxes are being paid, can be highly complex.

Beyond the legal context, there are a number of destination factors that organisations might factor into their IBT strategies. The emerging literature on expatriation to hostile 
environments (Pinto, Bader \& Schuster, 2017; Posthuma, Ramsey, Flores, Maertz, \& Ahmed, 2017; Bader, Schuster \& Dickmann 2019) explores some of the physical and psychological risks of working in dangerous contexts. While it seems likely that some of these insights might be transferred to IBTs (e.g. risk management approaches, training) some authors have suggested that multinationals might reduce their expatriate numbers in favour of increased use of IBTs (Mäkela, Kinnunen \& Suutari, 2015).

\section{Future research avenues.}

The management literature on international business travellers (IBTs) is even more sparse than the literature on short-term assignees. Overall, we know little about either the management or the personal problems of IBTs. More evidence about the existence and effects of specific work arrangements, career and development patterns as well as performance and reward implications specifically for IBTs would be a welcome addition to our understanding of these global workers. There are also issues with the assessment of the value of international business travel, particularly where it has a managerial or control function: is the impact of someone with little understanding of the local context, pressured to take quick decisions after a short visit, and then to fly off and leave local managers to deal with the fall-out, always going to be positive? The lack of understanding of the effects of IBTs on local teams and units, global configurations and particular business goals is hampering an assessment of IBT value and would provide an exciting area for further investigation.

More research is needed on the outcomes for the individuals concerned. What problems do they face and how might they be alleviated? Are the positive expectations some IBTs have (Demel \& Mayrhofer, 2010) likely to come to fruition and what would influence long-term career patterns of current or former IBTs? Westman et al. (2009b) argue that the positive impact of international travel such as improved business learning, individual growth, career impact of IBTs, getting to know new cultures, nations and regions has rarely been studied.

\section{INTERNATIONAL COMMUTERS}

Overview 
International commuters live in one country and work in another. Although there may be millions of such people, there is almost no research about them. For them, their journey to work involves crossing the border between the two countries. There are two different categories of international commuters: one is people who simply prefer to live in their home country and work in the neighbouring state; and one involves living in one country that is not home and commuting to one, or to others, that are also not home. We explore each in turn.

For commuters living at home, the decision to adopt a lifestyle of international commuting is usually taken by them, a self-initiated decision, it might be called, and their employer is either unconcerned with the decision or neutral about it (Mäkelä et al., 2017). Hence, they are unlikely to provide financial or any other support for the arrangement. For these people, as for domestic commuters (Sandow, 2014), travelling is simply a necessary part of their working lives. These kinds of arrangement are common in Europe, because of the number of countries in a relatively small land space and where, within the European Union, there are no restrictions on cross-border employment. France, for example, has land borders with eight other countries and many people prefer to live in France, where taxes are lower and work, for example, in Switzerland. People living in southern Sweden commute to Copenhagen by crossing the bridge that connects Sweden and Denmark, travelling across every weekday morning and back every evening. Crossing from the Czech republic to Austria may involve less than a 15-minute car journey to work (Mäkelä et al., 2017).

Other commuters do not live at home. In some intergovernmental agencies, in aid organisations and in religious groups, the work may be in turbulent, war-torn, or physically dangerous conditions. These people are expatriates in both the country that they and, sometimes, their family live in, and they are also international commuters, travelling regularly between that state and another.

Here, too, there will be employees from the shipping industry, with entire families relocating, usually from poorer countries such as Indonesia or Bangladesh to places such as Singapore or Hong Kong where the families can live in a nearby and attractive location (Dickie \& Dwyer, 2011), where work is available and where the family earners can commute to their work on ships or oil rigs. 


\section{Motives and barriers}

When cities are close togther, albeit across a national border, people can easily be mobile between the countries involved (Huber \& Nowotny, 2013). The choice of this form of international commuting may simply be a personal or family preference, but often the lifestyle, or living standards, in the home country are beneficial to the commuter, whilst the better work and higher salaries are available in the country where they work. Hence, for example, there are Uruguayans commuting to work in Brazil and Malaysians commuting to work in Singapore. It is particularly frequent for those in the unskilled workforce (domestic helpers, tradesmen, construction workers) commuting daily, weekly or monthly between two countries in order to earn a living. Their salaries are higher where they work, and they can live better on the money they make in their own country.

For the countries themselves (where the commuter works) there can be benefits such as cheaper labour and increased tax receipts, whilst the neighbouring state (where the commuter lives) loses those gains but does have the costs of community and social services, schooling and policing, etc. Accordingly, some states have spent heavily on transportation or reduced road tolls to improve systems and reduce travelling times to make such commuting easier (Knowles \& Matthiessen, 2009).

In some few cases, international commuting based on living at home may be employer initiated. For instance a company may promote a manager to a position where they are responsible for dealing with suppliers from three adjacent states. The manager continues to live at home but travels regularly to the other states to conduct their work, perhaps on a half-weekly, weekly or bi-weekly rota. The employer will be expected to pay for their travel and subsistence and perhaps to provide additional time off or extra leave to compensate for the commuting. Workers in industries such as oil and gas, typically travel to their country of work, or to their rig in international waters, on a monthly basis, working for 30 days on the rig and then having 30 days at home. Flight crew in the airlines or shipping employees will have work patterns matching the required transportation schedules (Mäkelä et al., 2017).

For the workers in less comfortable circumstances the main motives concern safety. Bodies such as the United Nations categorise locations around the world - some are categorised as 'non-family', meaning that the organisation feels that it is too dangerous to place the 
worker's family in that country (Cartus, 2012b). In such cases, the family may be left behind - in other cases families may relocate with the worker to a nearby country deemed to be safer, with the employee commuting on a regular basis to the state which they are trying to help (Fee \& McGrath-Champ, 2017; Mäkelä et al., 2017: 277).

\section{Management of international commuters}

For the commuters living at home there may be very little additional management involved: for them, their travel to work just happens to include crossing a national border (non-visibly in the EU for example, and often unattended as between, say, France and Switzerland). Their employer has no more interest in their journey to work than anyone else's journey to work.

There are, however, some limitations and considerations that do not necessarily apply to other international work forms. The international commuter may live in a country where the organisation does not have formal operations. For instance, a UK firm may not operate in Poland but may have some staff who work in a German factory just across the Polish border. On normal days these Polish workers commute to their German place of work. However, on those occasions where they have a 'home-office day' they run the risk that the Polish authorities might regard this as establishing an office in Poland. Thus, legal and tax compliance issues would arise, and companies would be well advised to not allow working from home for these international commuters.

For those employers motivated by concern for their employees' welfare, management becomes a key issue. By making such arrangements they have acknowledge the dangers involved and accepted an obligation of responsibility. Unfortunately, whilst we are beginning to get a better understanding of the management of expatriates in dangerous environments (Pinto, Bader \& Schuster, 2017; Posthuma, Ramsey, Flores, Maertz, \& Ahmed, 2017; Bader, Schuster \& Dickmann 2019), we have little knowledge of the issues involved in managing international commuting in such cases.

\section{Future research avenues.}

Given our almost total absence of information about international commuters, the research requirements are plain. We need to separate out the two main categories of commuters and then, in each case, to explore the motivation and management of these arrangements, 
and their negative and positive outcomes for individuals, families, organisations and colleagues. There is a rich research agenda here.

\section{CONCLUSIONS}

Overall, it seems that 'other' kinds of international working are growing faster than the more familiar forms of expatriation. Due to such growth and our lack of research evidence around such forms of mobility, we need further understanding of the special nature of such mobility. In Table 1, we compare the characteristics of the three types of international mobility we have discussed. Table 1 collects together the key points in what literature we have. A major research problem is that in many cases there is no central repository within organisations about these categories of worker. Because some of these types of international working (such as international commuting in the European Union) are organised by and controlled by individuals, and many of the other kinds (short-term contracts, frequent travel, etc) are organised and controlled by individual line managers and financed directly from their budgets, the human resource management specialists may not even know how many of these types of international workers the organisation has, never mind understand their issues and their potential. This makes research difficult. It may also be that some characteristics posed for certain type might also be relevant for other types, but those have not been raised in the literature. Further research is thus needed to fully understand the characteristics of these types of international work. 
Table 1: Comparing the main other types of international work

\begin{tabular}{|c|c|c|c|}
\hline & STAs & IBTs & $\begin{array}{l}\text { International } \\
\text { commuting }\end{array}$ \\
\hline $\begin{array}{l}\text { Common } \\
\text { features }\end{array}$ & \multicolumn{3}{|c|}{$\begin{array}{l}\text { No relocation of 'home' } \\
\text { Family does not usually travel: less family impacts than in long-term } \\
\text { expatriation \& less costs for the company } \\
\text { Salary/ tax/ etc all based on home location }\end{array}$} \\
\hline $\begin{array}{l}\text { Length of } \\
\text { international } \\
\text { work }\end{array}$ & $\begin{array}{l}\text { Short-term stay, } \\
\text { usually one to six } \\
\text { months. } \\
\text { In some project kind of } \\
\text { works, the work may } \\
\text { involve many STAs }\end{array}$ & $\begin{array}{l}\text { Usually just one or a } \\
\text { few days } \\
\text { Many jobs involve } \\
\text { frequent travelling }\end{array}$ & $\begin{array}{l}\text { Regular, periodic } \\
\text { travelling between two } \\
\text { locations }\end{array}$ \\
\hline $\begin{array}{l}\text { Main } \\
\text { individual } \\
\text { motivations }\end{array}$ & $\begin{array}{l}\text { Nature of work } \\
\text { Development } \\
\text { opportunities } \\
\text { International work } \\
\text { experience } \\
\text { Career development } \\
\text { A change of routine }\end{array}$ & $\begin{array}{l}\text { Nature of work } \\
\text { International travel } \\
\text { possibilities } \\
\text { Career development }\end{array}$ & $\begin{array}{l}\text { New work possibilities } \\
\text { Salary increases } \\
\text { Convenience for } \\
\text { commuter }\end{array}$ \\
\hline $\begin{array}{l}\text { Main } \\
\text { organizational } \\
\text { motivations }\end{array}$ & $\begin{array}{l}\text { Problem solving } \\
\text { Staffing problems } \\
\text { Project work } \\
\text { Management } \\
\text { development } \\
\text { Knowledge transfer } \\
\text { Control and } \\
\text { coordination }\end{array}$ & $\begin{array}{l}\text { Integration } \\
\text { Flexibility } \\
\text { Knowledge transfer } \\
\text { Innovation } \\
\text { Control and } \\
\text { coordination } \\
\text { Relationship building }\end{array}$ & $\begin{array}{l}\text { Flexibility } \\
\text { Staffing problems } \\
\text { Project work } \\
\text { Management } \\
\text { development }\end{array}$ \\
\hline $\begin{array}{l}\text { Individual } \\
\text { challenges }\end{array}$ & $\begin{array}{l}\text { Separation from family } \\
\text { Adjustment } \\
\text { Intensive work } \\
\text { Stress and fatique } \\
\text { Freetime possibilities }\end{array}$ & $\begin{array}{l}\text { Separation from family } \\
\text { Impacts on personal life } \\
\text { Stress of travel } \\
\text { Health issues }\end{array}$ & $\begin{array}{l}\text { Separation from family } \\
\text { Travel stress } \\
\text { Danger }\end{array}$ \\
\hline $\begin{array}{l}\text { Organisational } \\
\text { challenges }\end{array}$ & $\begin{array}{l}\text { Taxation and social } \\
\text { security issues } \\
\text { Visa and work permits } \\
\text { Responsibility } \\
\text { allocation (line and } \\
\text { HRM) } \\
\text { Control }\end{array}$ & $\begin{array}{l}\text { Travel arrangements } \\
\text { Legal compliance (e.g. } \\
\text { Visa) } \\
\text { Safety issues }\end{array}$ & $\begin{array}{l}\text { Risk of corporate } \\
\text { establishment of } \\
\text { business if commuter } \\
\text { works from home in a } \\
\text { country where } \\
\text { organization is not } \\
\text { incorporated }\end{array}$ \\
\hline $\begin{array}{l}\text { Future research } \\
\text { avenues }\end{array}$ & $\begin{array}{l}\text { Long-term individual } \\
\text { effects of STAs } \\
\text { Impact on families } \\
\text { Cost/ benefit } \\
\text { analysis } \\
\text { Repatriation } \\
\text { Management of STAs }\end{array}$ & $\begin{array}{l}\text { Variety of types of } \\
\text { international travel } \\
\text { Long-term effects of } \\
\text { travel } \\
\text { Cost/ benefit analysis } \\
\text { How long can } \\
\text { someone do this? }\end{array}$ & $\begin{array}{l}\text { Due to overall lack of } \\
\text { research, more } \\
\text { research is needed } \\
\text { both from individual } \\
\text { and organization } \\
\text { angles }\end{array}$ \\
\hline
\end{tabular}




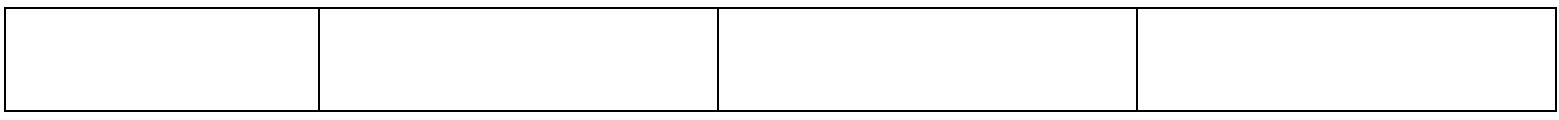

As noted throughout the chapter, our knowledge of such workers is generally thin: there is much that we do not know. These are areas of international mobility where the opportunities for further research appear fruitful, ultimately advancing not just our academic knowledge but also informing organisations, policy-makers as well as STAs, IBTs and cross-border commuters and their families of the likely benefits and potential threats to their careers, insights and lives.

Based on our review and discussion on future research avenues related with each type of international work in the text, we have suggested some areas for further research in Table 1. Even where we have evidence, it often comes just one or very few, often limited, studies. We thus have little information about different types of employees, and certain types of organisations or country contexts. It is difficult to generalise findings to other types of situation and we need further research to validate the observations. There is a fruitful research field here.

\section{REFERENCES}

Air Inc. (2012). Giving your managers wings: Flexible mobility policies that work. New York, NY: Air Inc.

Air Inc. (2017). Business Travel and Short-Term Assignment Survey Report. New York, NY: Air Inc.

Air Inc. (2018). Mobility Outlook Survey Report. New York, NY: Air Inc.

Allied Market Research (2018). Business Travel Market by service, industry, traveler - Global opportunity analysis and industry forecast. https://www.alliedmarketresearch.com/business-travel-market.

Bader, B., Schuster, T., \& Dickmann, M. (2019 forthcoming). Managing people in hostile environments: Lessons learned and new grounds in HR research. International Journal of Human Resource Management. https://doi.org/10.1080/09585192.2018.1548499 
Baker, C., \& Ciuk, S. (2015). Keeping the family side ticking along: An exploratory study of the work-family interface in the experiences of rotational assignees and frequent business travellers. Journal of Global Mobility, 3(2), 137-154.

Baruch, Y., Dickmann, M., Altman, Y., \& Bournois, F. (2013). Exploring international work: Types and dimensions of global careers. International Journal of Human Resource Management, 24(12), 2369-2393.

Bartlett, C. A., \& Ghoshal, S. (2002). Managing across borders: The transnational solution. Boston: Harvard Business Press.

Beaverstock, J., Derudder, J., Faulconbridge, J., \& Witlox, F. (2010). International Business Travel in The Global Economy. Surrey: Ashgate Publishing Ltd.

Blackman, A., Welters, R., Murphy, L., Eagle, L., Pearce, M., Pryce, J., Lynch, P., \& Low, D. 2014. Workers' perceptions of FIFO work in North Queensland, Australia. Australian Bulletin of Labour, 40(2): 180.

Bonache, J., Brewster, C., Suutari, V., \& Cerdin, J.-L. (2018). The changing nature of expatriation. Thunderbird International Business Review, 60(6), 815-821. DOI.org/10.1002/tie.21957.

Brewster, C., Harris, H., \& Petrovic, J. (2001). Globally mobile employees: Managing the mix. Journal of Professional HRM, 25, 11-15.

Brookfield Global Relocation Services. (2009). International Mobility: Introducing flexibility into policy structures. Woodridge, IL: Brookfield Global Relocation Services.

Brookfield GMAC (2013). Global Relocation Trends: 2013 Survey Report. Bun Ridge, IL, USA: Brookfield.

Caligiuri, P. (2012). Cultural agility: Building a pipeline of successful global professionals. John Wiley \& Sons.

Caligiuri, P. M., Hyland, M. M., Joshi, A., \& Bross, A. S. (1998). Testing a theoretical model for examining the relationship between family adjustment and expatriates' work adjustment. Journal of Applied Psychology, 83(4), 598.

Cartus. (2012b). Managing Expats in 'Unsafe' Locations. Wilmington, NC: Cartus.

Cartus. (2018). Biggest Challenges Survey Report. Danbury, CT: Cartus.

Collings, D., McDonnell, A., \& McCarter, A. (2015). Types of international assignees. In D. Collings, G. Wood \& P. Caligiuri (Eds.). Routledge Companion to International Human Resource Management (pp. 259-275). London: Routledge.

Collings, D. G., Scullion, H., \& Morley, M. J. (2007). Changing patterns of global staffing in the multinational enterprise: Challenges to the conventional expatriate assignment and emerging alternatives. Journal of World Business, 42(2), 198-213.

Crowley-Henry, M., \& Heaslip, G. (2014). Short-term assignments. Military perspectives and implications for international human resource management. European Management Journal, 32, 752-760.

Crowne, K. A., \& Engle, R. (2016). Antecedents of cross-cultural adaptation stress in shortterm international assignments. Organization Management Journal, 13(1), 32-47.

Davidson, R., \& Cope, B. (2003). Business Travel: Conferences, incentive travel, exhibitions, corporate hospitality and corporate travel. New York: Pearson Education.

DeFrank, R., Konopaske, R., \& Ivancevich, J. (2000). Executive travel stress: Perils of the road warrior. Academy of Management Executive, 14, 58-71.

Demel, B., \& Mayrhofer, W. (2010). Frequent business travelers across Europe: Career aspirations and implications. Thunderbird International Business Review, 52(4), 301311. 
Dickie, C., \& Dwyer, J. (2011). A 2009 perspective of HR practices in Australian mining. Journal of Management Development, 30(4), 329-343.

Dickmann, M. (2015). Programme Management and Technology, Chapter 5 (pp. 88-99) in M. Dickmann, Strategic Global Mobility \& the Talent Management Conundrum. The RES Forum Annual Report 2015, London: RES Forum.

Dickmann, M. (2016). Beyond Uniformity - A world of opportunity. The RES Forum Annual Report 2016, London: RES Forum.

Dickmann, M. (2018). Global Mobility of the Future - Smart, Agile, Flawless and Efficient. 157 pages, The RES Forum Annual Report, London: RES Forum, Harmony Relocation Network and Equus Software.

Dickmann, M., \& Baruch, Y. (2011). Global Careers. London: Routledge.

Dickmann, M., \& Müller-Camen, M. (2006). A typology of international human resource management strategies and processes. International Journal of Human Resource Management, 17(4), 580-601.

Dickmann, M., Suutari, V., \& Wurtz, O. (2018). The multiple forms and shifting landscapes of global careers. In Dickmann, M., Suutari, V. \& Wurtz, O. (Eds). The Management of Global Careers. Exploring the Rise of International Work. Cham: Palgrave Macmillan.

Duxbury, A. (2018). Commuter assignments - the consequences beyond the financial cost. London: ECA International.

ECA International. (2016). The decline of the traditional expatriate. https://www.ecainternational.com/insights/articles/may-2016/the-decline-of-the-traditional-expat

Edström, A., \& Galbraith, J. R. (1977). Transfer of managers as a coordination and control strategy in multinational organizations. Administrative Science Quarterly, 248-263.

Espino, C., Sundstrom, S., Frick, H., Jacobs, M., \& Peters, M. (2002). International business travel: Impact on families and travellers. Occupational and Environmental Medicine, 59(3), 309-322.

Fee, A., \& McGrath-Champ, S. (2017). The role of human resources in protecting expatriates: insights from the international aid and development sector. International Journal of Human Resource Management, 28(14), 1960-1985.

Harjo, E., Chung, C. \& Brewster, C. (date) Are they different? International assignment motivations of short-term expatriates from an emerging economy. Asia Pacific Journal of Human Resource Management

Harris, H., Brewster, C., \& Sparrow, P. (2003). International Human Resource Management. London: CIPD Publishing.

Harvey, M., Mayerhofer, H., Hartmann, L., \& Moeller, M. (2010). Corralling the 'horses' to staff the global organization of 21st century. Organization Dynamics, 39(3), 258-268.

Haslberger, A., Brewster, C., \& Hippler, T. (2014). Managing Performance Abroad: a new model for understanding expatriate adjustment London: Routledge.

Hocking, B. J., Brown, M., \& Harzing, A. W. (2004). A knowledge transfer perspective of strategic assignment purposes and their path-dependent outcomes. International Journal of Human Resource Management, 15(3), 565-586.

Hovhannisyan, N., \& Keller, W. (2015). International business travel: an engine of innovation? Journal of Economic Growth, 20(1), 75-104.

Huber, P., \& Nowotny, K. (2013). Moving across borders: Who is willing to migrate or to commute? Regional Studies, 47(9), 1462-1481.

Johnson, L. (2017). Smart Moves: Companies look to lower the cost of global mobility. Danbury, CT: Crown World Mobility. 
Kang, H., Shen, J., \& Benson, J. (2016). Not all expatriates are the same: Non-traditional South Korean expatriates in China. International Journal of Human Resource Management, 28(13), 1842-1865.

Kedia, B. L., \& Mukherji, A. (1999). Global managers: Developing a mindset for global competitiveness. Journal of World Business, 34(3), 230-251.

Knowles, R., \& Matthiessen, C. (2009). Barrier effects of international borders on fixed link traffic generation: The case of $\varnothing$ resundsbron. Journal of Transport Geography, 17(3), 155-165.

KPMG. (2017). Global Assignment Policies and Practices Survey. Geneva: KPMG.

Lazarova, M., Westman, M., \& Shaffer, M. A. (2010). Elucidating the positive side of the work-family interface on international assignments: A model of expatriate work and family performance. Academy of Management Review, 35(1), 93-117.

Mäkelä, K., \& Brewster, C. (2009). Interunit interaction contexts, interpersonal social capital, and differing levels of knowledge sharing. Human Resource Management, 48(4): 591614.

Mäkelä, L., Bergbom, B., Tanskanen, J., \& Kinnunen, U. (2014). The relationship between international business travel and sleep problems via work-family conflict. Career Development International, 19(7), 794-812.

Mäkelä, L., Kinnunen, U., \& Suutari, V. (2015). Work-to-life conflict and enrichment among international business travelers: The role of international career orientation. Human Resource Management, 54(3), 517-531.

Mäkelä, L., Saarenpää, K., \& McNulty, Y. (2017). International business travelers, short-term assignees and international commuters. In Y. McNulty \& J. Selmer (Eds.). Research Handbook of Expatriates (pp. 276-294). London: Edward Elgar.

Mayrhofer, W., \& Scullion, H. (2002). Female expatriates in international business: Empirical evidence from the German clothing industry. International Journal of Human Resource Management, 13, 815-836

McNulty, Y. (2015). Till stress do us part: The causes and consequences of expatriate divorce. Journal of Global Mobility, 3(2), 106-136.

McNulty, Y., \& Brewster, C. (2017). Theorising the meaning(s) of 'expatriate': establishing boundary conditions. International Journal of Human Resource Management 28(1), 27-61

McNulty, Y., \& Brewster, C. (2019). Working Internationally: expatriation, migration and other global work. Cheltenham: Edward Elgar.

McNulty, Y., De Cieri, H., \& Hutchings, K. (2009). Do global firms measure expatriate return on investment? An empirical examination of measures, barriers and variables influencing global staffing practices. International Journal of Human Resource Management, 20(6), 1309-1326.

Mercer (2016). Exploring smarter global mobility strategies. Mercer: London. https://mobilityexchange.mercer.com/Insights/mobility-guides

Meyskens, M., Von Glinow, M., Werther, W., \& Clarke, L. (2009). The Paradox of international talent: Alternative forms of international management. International Journal of Human Resource Management, 20(6), 1439-1450.

Minbaeva, D., \& Michailova, S. (2004). Knowledge transfer and expatriation in multinational corporations: The role of disseminative capacity. Employee Relations, 26(6), 663-679.

Phillips, J. M., Gully, S. M., McCarthy, J. E., Castellano, W. G., \& Kim, M. S. (2014). Recruiting global travelers: The role of global travel recruitment messages and individual 
differences in perceived fit, attraction, and job pursuit intentions. Personnel Psychology, 67(1), 153-201.

Pinto, L. H. F., Bader, B., \& Schuster, T. (2017). Dangerous settings and risky international assignments. Journal of Global Mobility, 5(4), 342-347.

Posthuma, R. A., Ramsey, J. R., Flores, G. L., Maertz, C., \& Ahmed, R. O. (2017). A risk management model for research on expatriates in hostile work environments. International Journal of Human Resource Management, 1-17.

Reiche, B. S., Harzing, A-W, \& Kraimer, M. (2009). The role of international assignees' social capital in creating inter-unit intellectual capital: A cross-level model. Journal of International Business Studies, 40(3), 509-526.

Renshaw, P. S. J., Parry, E., \& Dickmann, M. (2018). Seconded National Experts and global mobility - Extending the paradigm. Thunderbird International Business Review, 60(6), 897-909.

Rogers, H. L. (1998). A Survey of the Travel Health Experiences of International Business Travelers. Calgary.

Saarenpää, K. (2017). Stretching, adapting and negotiating: International business travel and its influence on work-family interaction. PhD, University of Vaasa, Finland.

Salleh, N., \& Koh, J. (2013). Analysing the functions of short-term expatriate assignments. Procedia - Social and Behavioral Sciences, 107, 34-42.

Sandow, E. (2014). Til work do us part: The social fallacy of long-distance commuting. Urban Studies, 51(3), 526-543.

Shaffer, M., Kraimer, M., Chen, Y-P., \& Bolino, M. (2012). Choices, challenges, and career consequences of global work experiences : A review and future agenda. Journal of Management, 38(4), 1282-1327.

Starr, C. (2009). Repatriation and short-term assignments: An exploration into expectations, change and dilemmas. International Journal of Human Resource Management, 20(2), 286-300.

Starr, T., \& Currie, G. (2009). 'Out of sight, but still in the picture': Short-term international assignments and the influential role of family. International Journal of Human Resource Management, 20(6), 1421-1438.

Striker, J., Luippold, R., Nagy, L., Liese, B., Bigelow, C., \& Mundt, K. (1999). Risk factors for psychological stress among international business travellers. Occupational and Environmental Medicine, 56(4), 245-252.

Suutari, V., \& Brewster, C. (2009). Beyond expatriation: Different forms of international employment. In P. Sparrow (Ed.). Handbook of International Human Resource Management: Integrating people, process and context (pp. 131-150). Chichester, UK: Wiley.

Suutari, V., Brewster, C., Riusala, K., \& Syrjakari, S. (2013). Managing non-standard international experience: Evidence from a finnish company. Journal of Global Mobility, 1(2), 118-138.

Suutari, V., \& Brewster, C. (2009). Beyond expatriation: different forms of international employment. In P. Sparrow (Ed). Handbook of International Human Resource Management: integrating people, process and context. Wiley, Chichester (131-150).

Suutari, V., Brewster, C., Riusala, K., \& Syrjäkari, S. (2013). Managing short-term assignments: Evidence from a Finnish company. Journal of Global Mobility, 1(2), 118138. 
Tahvanainen, M., Welch, C., \& Worm, V. (2005). Implications of short term international assignments. European Management Journal, 23(6), 663-673.

Tharenou, P., \& Harvey, M. (2006). Examining the overseas staffing options utilized by Australian headquartered multinational corporations. International Journal of Human Resource Management, 17(6), 1095-1114.

Welch, D., \& Worm, V. (2006). International business travellers: A challenge for IHRM. In G. Stahl \& I. Björkman (Eds.). Handbook of Research in International Human Resource Management (pp. 283-301). Cheltenham, UK: Edward Elgar.

Westman, M., \& Etzion, D. (2002). The impact of short overseas business trips on job stress and burnout. Applied Psychology: An International Review, 51(4), 582-592.

Westman, M., Etzion, D., \& Chen, S. (2009a). The crossover of exhaustion and vigor between international business travelers and their spouses. Journal of Managerial Psychology, 24, 269-284.

Westman, M., Etzion, D., \& Chen, S. (2009b). Crossover of positive experiences from business travelers to their spouses. Journal of Managerial Psychology, 24(3), 269284.

Wurtz, O. (2018). Expatriation, alcohol and drugs: antecedents and consequences of substance use in expatriation. Journal of Global Mobility, 6(3/4), 316-334. 